\title{
Tantangan dan Strategi UMKM Milik Keluarga (Bisnis Keluarga) Bidang Makanan dan Minuman dalam Menghadapi Kebijakan Pembatasan Sosial Berskala Besar selama Pandemi Virus Corona (Covid-19) di Indonesia
}

\author{
Laura Stefanie Kwa \\ Program Studi Manajemen, Universitas Ma Chung, Villa Puncak Tidar No.1, Karangwidoro, Dau, Malang, \\ Indonesia, Jawa Timur 65151
}

Correspondence: Liem Gai Sin, SE., M.Bus(Adv) (liem.gaisin@machung.ac.id)
Sarbini Wono (sarbiniwono@gmail.com)
Received: 290721 - Revised: 290721 - Accepted: 170821 - Published: 28092

\begin{abstract}
Abstrak. Keberadaan UMKM sangat penting bagi pertumbuhan ekonomi Indonesia. Namun, sejak Covid-19 pertama kali dikonfirmasi menyebar di Indonesia, kinerja UMKM mengalami penurunan penjualan. UMKM dalam bidang makanan dan minuman, khususnya yang dikelola oleh keluarga, merupakan salah satu industri yang paling terdampak akibat Covid-19. Penelitian ini menggunakan metode studi kepustakaan untuk menganalisis hal-hal yang berkaitan dengan penurunan penjualan UMKM dalam bidang makanan dan minuman, khususnya yang dikelola oleh keluarga. Hasil penelitian menunjukan penurunan terjadi setelah ditetapkannya kebijakan Pembatasan Sosial Berskala Besar sebagai salah satu upaya pemerintah (daerah) untuk meminimalisir penularan Covid-19. Penelitian menunjukan penurunan omzet hingga 50\%, bahkan penurunan penjualan hingga hingga 90\% pada UMKM keluarga dalam bidang makanan dan minuman. Oleh karena itu, strategi-strategi pengelolaan usaha untuk mempertahankan UMKM selama masa pandemi Covid-19 perlu dilakukan meskipun pemerintah telah menetapkan kebijakan untuk memperpanjang tenggat waktu dan mengurangi bunga pinjaman untuk UMKM.
\end{abstract}

Kata kunci: UMKM, UMKM keluarga bidang makanan dan minuman, Covid-19, PSBB.

Citation Format: Kwa,L.S,. (2020). Tantangan dan Strategi UMKM Milik Keluarga (Bisnis Keluarga) Bidang Makanan dan Minuman dalam Menghadapi Kebijakan Pembatasan Sosial Berskala Besar Selama Pandemi Virus Corona (Covid-19) di Indonesia. Prosiding Seminar Nasional Abdimas Ma Chung (SENAM), 2020, 78-89. 


\section{PENDAHULUAN}

UMKM merupakan singkatan dari Usaha Mikro, Kecil, dan Menengah. Sebagian besar UMKM termasuk ke dalam 95\% bisnis di Indonesia yang dikategorikan sebagai bisnis keluarga (PwC, 2014), karena menurut survei yang dilakukan oleh Bank Indonesia dan Lembaga Pengembangan Perbankan Indonesia (2015), UMKM seringkali dikelola oleh keluarga. Karena itu, UMKM juga dapat disebut sebagai penopang perekonomian rumah tangga.

Selain menjadi penopang bagi perekonomian rumah tangga, keberadaan UMKM juga sangat penting bagi pertumbuhan ekonomi Indonesia (Hayashi dalam Hamzani \& Achmad, 2017). Menurut data Kementerian Koperasi dan UKM Republik Indonesia, UMKM memiliki pangsa pasar sekitar 99,99\% (62,9 juta unit) dari total keseluruhan pelaku usaha di Indonesia (Haryanti \& Hidayah, 2018). Sedangkan, menurut UKM Crisis Center, UMKM berkontribusi sekitar 60\% terhadap Produk Domestik Bruto (PDB) Indonesia (Hidranto, 2020). UMKM juga merupakan lapangan kerja terbesar di Indonesia yang telah menyerap 97,30\% dari tenaga kerja negara (Yasa, 2016).

Meskipun demikian, sejak Covid-19 (wabah penyakit menular yang disebabkan oleh sindrom pernafasan akut yang parah virus Corona 2 (SARS-CoV-2) pertama kali dikonfirmasi menyebar di Indonesia pada 2 Maret 2020 (Staff, 2021), kinerja UMKM di beberapa wilayah Indonesia mengalami penurunan penjualan. Penurunan penjualan UMKM terjadi setelah ditetapkannya kebijakan Pembatasan Sosial Berskala Besar (PSBB) sebagai salah satu upaya pemerintah (daerah) di Indonesia untuk memutus dan mencegah penyebaran Covid-19 agar tidak semakin meluas (Wijaya, 2020).

Penurunan penjualan pada UMKM dipaparkan oleh Wakil Ketua Umum Asosiasi Pengusaha Indonesia (Apindo), Shinta W. Kamdani (Herlinda, 2020), bahwa secara umum kalangan pebisnis sangat mengapresiasi kebijakan pemerintah mengenai PSBB. Namun, secara ekonomi, dampak yang diberikan PSBB terhadap dunia bisnis cukup signifikan. Ia menyatakan, PSBB mendorong beberapa bisnis untuk menurunkan kapasitas produksinya akibat bahan baku dan operasional yang terbatas karena pergerakan rantai pasok yang tertekan oleh PSBB. Hal ini didukung oleh pernyataan Bhima Yudhistira Adhinegara (2020), seorang ekonom Institute for Development of Economics and Finance (INDEF) yang menyatakan bahwa pemberlakuan PSBB berdampak terhadap sektor bisnis Indonesia, terutama bagi pelaku usaha mikro, kecil, dan menengah (UMKM) (Lidyana, 2020). 
Dalam telekonferensi pada 16 April 2020, Staf Khusus Menteri Koperasi dan UKM Bidang Pemberdayaan Ekonomi Kreatif, Fiki Satari, mengatakan bahwa secara umum, 56\% usaha kecil dan menengah di Indonesia mengalami penurunan penjualan. Hal tersebut $22 \%$ disebabkan oleh permodalan, $15 \%$ karena terhambatnya proses distribusi, dan 4\% disebabkan oleh kelangkaan bahan baku akibat Covid-19 (Nurhidayat, 2020). Sedangkan menurut survei UKM Crisis Center sebanyak 36,7\% UMKM mengaku penjualan terhenti selama pandemi Covid-19, dan 26\% persen UMKM menyebutkan mereka mengalami penurunan penjualan lebih dari 60\% (Hidranto, 2020).

UMKM yang bergerak dalam industri makanan dan minuman merupakan salah satu yang paling terpukul selama pandemi Covid-19 (Deloitte, 2020). Berdasarkan catatan Himpunan Pengusaha Muda Indonesia (HIPMI), UMKM yang bergerak dalam industri makanan dan minuman telah mengalami penurunan penjualan sekitar 30\% (Aminah, 2020).

Penurunan penjualan secara terus-menerus selama pandemi Covid-19 dapat menyebabkan kerugian yang semakin besar bagi pelaku usaha yang kemudian dapat mengakibatkan Pemutusan Hubungan Kerja (PHK), bahkan penutupan usaha. Mengingat kontribusi UMKM terhadap perekonomian Indonesia ((Haryanti \& Hidayah, 2018); UKM Crisis Center dalam Hidranto (2020); dan (Yasa, 2016)), dampak dari kerugian UMKM tersebut dapat mengganggu stabilitas perekonomian nasional, seperti penurunan PDB dan peningkatkan tingkat pengangguran.

Oleh karena itu, mengingat pentingnya kontribusi UMKM terhadap perekonomian nasional, penelitian ini bertujuan untuk menganalisis masalah terkait (1) bagaimana pengaruh kebijakan PSBB terhadap usaha mikro, kecil, dan menengah yang dimiliki oleh keluarga, khususnya yang bergerak dalam bidang makanan dan minuman selama masa pandemi Covid-19, (2) apa saja tantangan yang dihadapi UMKM, khususnya bagi UMKM di bidang makanan dan minuman yang dikelola oleh keluarga dalam masa PSBB selama pandemi Covid-19, dan (3) bagaimana strategi-strategi preventif yang dapat dilakukan pelaku usaha UMKM sebagai bisnis keluarga untuk meminimalisir kerugian selama masa pandemi Covid-19 demi menjaga kesinambungan usaha dan stabilitas perekonomian nasional.

Berdasarkan uraian di atas, hasil penelitian ini diharapkan dapat memberikan gambaran mengenai kondisi UMKM selama masa pandemi Covid-19, khususnya yang dimiliki oleh keluarga dan bergerak dalam bidang makanan dan minuman kepada pemerintah agar dapat dijadikan landasan dalam menetapkan kebijakan-kebijakan lainnya 
mengenai UMKM yang terdampak Covid-19, maupun pedoman bagi pelaku usaha dalam mengimplementasikan strategi khususnya lingkup mikro, kecil dan menengah yang bergerak sebagai bisnis keluarga, terutama dalam bidang makanan dan minuman agar dapat bertahan selama masa pandemi Covid-19.

\section{METODE PELAKSANAAN}

Metode yang digunakan dalam penelitian ini adalah studi kepustakaan. Studi kepustakaan atau penelitian kepustakaan merupakan metode penelitian yang berkenaan dengan metode pengumpulan data pustaka, atau penelitian yang obyek penelitiannya digali melalui beragam informasi kepustakaan (Syaodih, 2009). Jenis data yang digunakan oleh penulis dalam penelitian ini adalah data sekunder yang diperoleh atau dikumpulkan dari orang lain yang telah melakukan penelitian dari sumber-sumber yang telah ada (Hasan, 2002). Data sekunder yang digunakan oleh penulis dalam penelitian ini berupa jurnal ilmiah (tercetak dan/atau non-cetak), berita-berita, hasil survey, maupun undang-undang yang berkenaan dengan topik yang dikaji. Penulis kemudian menguraikan dan mendeksripsikan secara sistematis data yang telah diperoleh untuk memberikan pemahaman dan penjelasan agar dapat dipahami dengan baik oleh pembaca.

\section{HASIL DAN PEMBAHASAN}

Indonesia merupakan salah satu negara berkembang di Asia Tenggara. Seperti negara-negara berkembang lainnya, UMKM merupakan sarana pemerataan kesejahteraan ekonomi dan sosial terbesar di Indonesia, dimana keberadaan UMKM merupakan solusi yang efektif bagi permasalahan ekonomi masyarakat khususnya bagi kelas kecil dan menengah. Hal ini didukung oleh data Kementerian Koperasi dan Usaha Kecil dan Menengah Republik Indonesia tentang Perkembangan Data Usaha Mikro, Kecil, Menengah (UMKM) dan Usaha Besar (UB) Tahun 2016-2017, Usaha Mikro, Kecil dan menengah (UMKM) berjumlah sebesar 62.922.617 unit usaha dan mencakup sekitar 99\% dari perusahaan bisnis yang ada di Indonesia (Capri, 2018). Dengan itu, UMKM memiliki peran strategis dalam pertumbuhan ekonomi dan mengurangi pengangguran di Indonesia (Samsiah \& Lawita, 2017). UMKM juga berkontribusi terhadap produk domestik bruto (PDB) sebanyak 57-60\% dan menyerap tenaga kerja hingga 97\% (LPPI \& BI, 2015).

Berdasarkan data Kementrian Koperasi dan UMKM Indonesia tahun 2014, UMKM di Indonesia terdiri dari beberapa unit usaha dengan jumlah sebagai berikut: 


\section{Gambar}

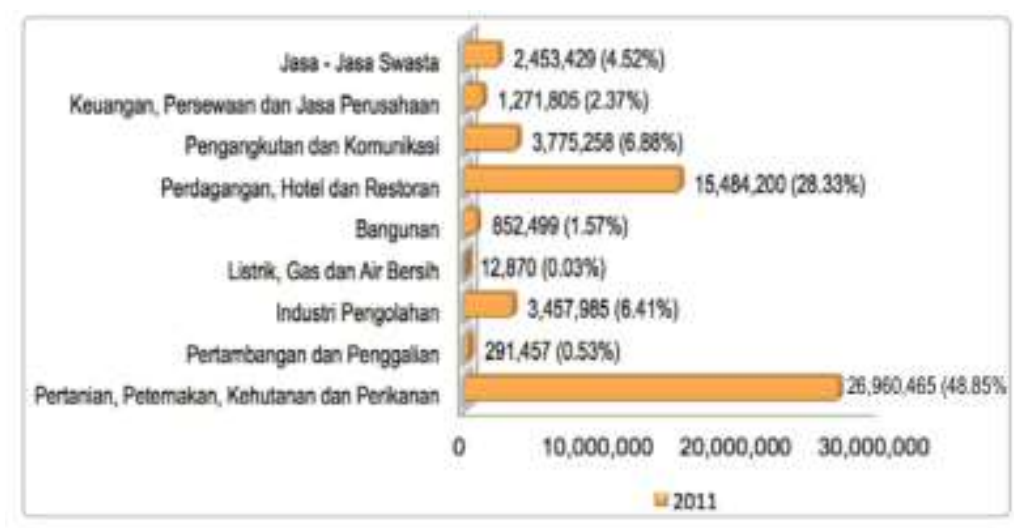

Sumber : Kementerian Koperasi dan UMKM, 2014

1. Persentase

UMKM Indonesia 2014

Sehingga, kontribusi UMKM terhadap PDB Indonesia merupakan akumulasi dari beberapa sektor ekonomi, yaitu (i) Pertanian, Peternakan, Kehutanan dan Perikanan (48,85\%), (ii) Perdagangan, Hotel dan Restoran (28,83\%), (iii) Pengangkutan dan Komunikasi (6,88\%), (iv) Industri Pengolahan (6,41\%), (v) Jasa-jasa (4,52\%), (vi) Keuangan, Persewaan dan Jasa Perusahaan (2,37\%), (vii) Bangunan (1,57\%), (viii) Pertambangan dan Penggalian (0,53\%), (ix) Listrik, Gas dan Air Bersih (0,03\%) (LPPI dan BI, 2015).

Sejak tahun 2017, UMKM dalam bidang makanan dan minuman berkembang dengan pesat di Indonesia. Hal ini didukung oleh data yang diterbitkan oleh Kementrian Perindustrian Republik Indonesia pada tahun 2017 mengenai pertumbuhan industri makanan dan minuman yang mencapai 9,23\%. Persentase tersebut menujukan peningkatan dari 2016 yang mencapai $8,46 \%$. Pertumbuhan yang pesat tersebut membuat Menteri Perindustrian Republik Indonesia, Airlangga Hartarto (n.d) menyatakan bahwa UMKM yang bergerak dalam bidang makanan dan minuman (masuk ke dalam unit perdangan, hotel dan restoran) menjadi salah satu subsektor motor pertumbuhan ekonomi Indonesia.

Data dari Kementrian Perindustrian Republik Indonesia didukung oleh hasil survey yang dilakukan oleh Mahardika dalam Forbil (n.d.), menyatakan bahwa pertumbuhan industri makanan dan minuman didorong oleh keterlibatan UMKM. Pada tahun 2010, jumlah usaha makanan dan minuman dengan kategori usaha kecil dan mikro mencapai 960.305 perusahaan dan meningkat hingga mencapai 1.614.149 perusahaan pada tahun 2015 . Sedangkan, berdasarkan survey yang dilakukan oleh The Indonesian Institute, pada tahun 2017, jumlah UMKM dalam bidang makanan dan minuman adalah 3.694 .122 unit dan 
jumlah tenaga kerja yang terserap 13.892.453 orang, dengan jumlah output sebesar 4.857 triliun rupiah (Amelia, Purbolaksono, \& Syahayani, 2017).

Dengan tingginya tingkat pertumbuhan UMKM bidang makanan dan minuman, menurut data terbaru Kementrian Perindustrian Repubik Indonesia, pada tahun 2018 sektor UMKM bidang makanan dan minuman mampu memberikan kontribusi tertinggi dibandingkan sektor-sektor lainnya terhadap PDB industri pengolahan nonmigas hingga 35,87\% (Paramaesti, 2018).

Meskipun demikian, PSBB yang diterapkan pada beberapa daerah di Indonesia sebagai upaya pemerintah dalam mengurangi dan mencegah penyebaran maupun penularan Covid-19 telah memberikan dampak penurunan yang signifikan terhadap perekonomian. Menurut Menteri Keuangan Republik Indonesia, Sri Mulyani, kebijakan PSBB memperlambat aktivitas ekonomi (supply and demand), sehingga menurunkan pendapatan masyarakat secara drastis, dan bahkan memaksa beberapa usaha untuk menutup bisnis mereka dalam jangka waktu yang tidak pasti (Widyamurti, 2020). Berdasarkan survei Moka, UMKM yang bergerak dalam bidang makanan dan minuman merupakan salah satu industri yang paling terdampak akibat penyebaran virus corona atau Covid-19 yang makin meluas di tanah air (Pernando, 2020).

Hasil survei yang dilakukan oleh Moka didukung oleh hasil survei Smesco Indonesia, salah satu institusi dibawah naungan Kementerian Koperasi dan UKM, yang juga memaparkan hasil bahwa UMKM dalam bidang makanan dan minuman merupakan yang paling banyak terpukul akibat Covid-19 (Waseso, 2020). Menurut Direktur Jenderal Industri Kecil Menengah dan Aneka (IKMA) Kemenperin, Gati Wibawaningsih, bisnis makanan dan minuman dengan skala mikro, kecil, dan menengah pada daerah-daerah yang diberlakukan PSBB mengalami penurunan omzet hingga 50\%, bahkan penurunan penjualan hingga hingga 90\% (Putra, 2020).

Menurut hasil SurveySensum, penurunan pendapatan pada UMKM dalam bidang makanan dan minuman diakibatkan oleh penurunan drastis akitivitas konsumen di luar rumah selama pandemi Covid-19 (Burhan, 2020). Sekitar 90\% konsumen merasa kehidupan sehari-harinya terganggu sejak merebaknya Covid-19. Para konsumen mengalami kondisi psikologis takut tertular penyakit sehingga lebih memilih untuk berada di rumah. Sehingga, transaksi untuk makan dan minum di tempat selama PSBB diberlakukan hanya 5\%. Selain itu, kebijakan PSBB juga mengganggu aktivitas produksi dan distribusi produk UMKM, karena distribusi pasokan barang mentah untuk produksi UMKM tersendat akibat 
pemberlakuan penutupan wilayah maupun pengurangan aktivitas pengiriman barang (Harmawan, 2020).

Berdasarkan kepemilikannya, UMKM dalam bidang makanan dan minuman sebagai bisnis keluarga terdampak lebih dari signifikan, baik dalam sisi finansial maupun non finansial. Selama masa kebijakan PSBB diberlakukan, alasan lain dari penyebab menurunnya pendapatan pada UMKM bidang makanan dan minuman yang dikelola dan dijalankan oleh keluarga selain penurunan drastis aktivitas konsumen di luar rumah dan menurunnya kapasitas produksi akibat terganggungnya proses distribusi bahan baku akibat PSBB adalah menurunnya produktivitas dan konsentrasi kerja karena sebagian besar pekerja (yang umumnya merupakan pemilik langsung ataupun pekerja yang merupakan anggota keluarga pemilik) harus menjadi lebih fokus pada anak-anak mereka karena sistem pembelajaran online yang dilakukan dari rumah.

Selain itu, UMKM yang dikelola oleh keluarga dalam bidang makanan dan minuman cenderung menggunakan teknologi yang relatif sederhana, sistem manajemen tidak profesional, kurang memiliki akses terhadap permodalan, kondisi keuangan yang tidak stabil, dan tidak ada pemisahan modal usaha dengan kebutuhan pribadi sehingga seringkali mengakibatkan minimnya inovasi strategi maupun produk (Mahlizal, Priatna, \& Burhanuddin, 2016; Rahadi, 2017). Hal tersebut inilah yang membuat beberapa UMKM di bidang makanan dan minuman yang dikelola oleh keluarga seringkali kalah bersaing dan terpuruk dalam masa pandemi Covid-19.

Oleh karena itu, meskipun pemerintah telah menetapkan kebijakan untuk memperpanjang tenggat waktu dan mengurangi bunga pinjaman untuk UMKM yang terkena dampak pandemi Covid-19 pada 16 Maret 2020 (Regulasi OJK (POJK) No. 11/POJK.03/2020) maupun membebaskan pajak penghasilan akhir untuk UMKM dan memberikan bantuan keuangan untuk modal bagi UMKM yang terdampak pandemi Covid-19, strategi-strategi pengelolaan usaha selama masa pandemi tetap perlu dilakukan oleh pelaku usaha UMKM, khususnya dalam bidang makanan dan minuman yang dikelola oleh keluarga demi terjaganya kesinambungan usaha dan stabilitas perekonomian nasional. Berikut ini adalah beberapa upaya yang dapat dilakukan UMKM bidang makanan dan minuman yang dikelola oleh keluarga:

\section{1 ) Penjualan dan Pemasaran Secara Online.}

Menteri Koperasi dan UKM, Teten Masduki mengungkapkan transaksi penjualan online meningkat hingga $350 \%$ di tengah pandemi Covid-19 (CNN, 2020). 
Sedangkan, menurut data e-commerce enabler Sirclo, peningkatan permintaan yang terjadi pada produk UMKM makanan dan minuman secara online mencapai 143\% selama masa PSBB (Iskandar, 2020). Oleh karena itu, agar dapat bersaing dan bertahan dalam masa pandemi Covid-19, pelaku usaha perlu bersikap adaptif terhadap kemajuan teknologi dengan memanfaatkan sistem penjualan online. Penjualan online harus didukung dengan pemasaran online melalui sosial media.

\section{2) Inovasi Produk.}

UMKM makanan dan minuman menerapkan strategi khusus seperti mengeluarkan produk makanan beku, ataupun minuman literan yang dapat disimpan oleh konsumen dalam jangka waktu yang lebih lama sehingga menciptakan tren baru dalam bisnis kuliner (Setyowati, 2020). Hal ini menuntut pelaku UMKM untuk harus mampu melakukan inovasi terhadap produk agar sesuai dengan permintaan konsumen selama masa pandemi Covid-19 berlangsung.

\section{3) Menjaga Kepercayaan Konsumen Dengan Menerapkan dan Menginformasikan}

\section{Penerapan Kebersihan sesuai dengan anjuran pemerintah serta Standar Keamanan}

\section{Terpadu untuk Layanan Pesan-antar Makanan.}

Pelaku usaha harus mewajibkan pemakaian masker dan sarung tangan untuk seluruh karyawan serta melakukan pengecekan harian suhu tubuh karyawan. Hal ini dilakukan untuk meyakinkan konsumen bahwa produk makanan dan minuman yang dibeli tidak menjadi perantara penyebaran Covid-19.

4) Mengkomunikasikan dan Merencanakan Kebijakan untuk 3 sampai 18 Bulan ke Depan dengan Anggota Keluarga yang Terlibat dalam UMKM.

Sulit untuk mengukur berapa lama pandemi Covid-19 akan berlangsung. Oleh karena itu, penting bagi pelaku usaha UMKM, khususnya dalam bidang makanan dan minuman yang dikelola oleh keluarga untuk mempersiapkan berbagai macam skenario. Misal, jika kritis terjadi selama 3 bulan, strategi dengan meminimalisir pengeluaran secara sementara dapat meringankan beban bisnis. Namun, apabila krisis berlanjut selama 9 bulan hingga 1 tahun, maka pelaku usaha harus mampu mengkonfigurasi ulang strategi bisnis untuk mengurangi biaya variabel, menegosiasikan kembali biaya tetap (sewa, gaji, pembayaran sewa peralatan, dan lain sebagainya), serta fokus pada hal-hal krusial lainnya untuk mempertahankan keberlangsungan UMKM. Apabila pandemi Covid-19 berlanjut hingga 18 atau lebih, maka beberapa pertimbangan serius diperlukan bulan atau lebih. Misalnya, 
UMKM perlu merevisi kembali target pendapatan penjualan dengan rencana operasional yang baru.

\section{5) Pro Aktif dalam Mencari Informasi Terbaru Mengenai Covid-19 di Indonesia.}

Bersikap pro aktif dalam mencari sumber informasi terpercaya mengenai perkembangan terbaru tentang informasi yang berkaitan dengan Covid-19. Kebijakan yang sewaktu-waktu dapat diterapkan oleh pemerintah sebagai upaya penangan Covid-19 dapat mempengaruhi strategi-strategi yang telah ditetapkan UMKM.

\section{6) Memisahkan Keuangan UMKM dengan Keuangan Pribadi dan Menyusun Laporan}

\section{Keuangan.}

Salah satu karakterisitik dari UMKM yang dimiliki dan dikelola oleh keluarga adalah tidak ada pemisahan keuangan UMKM dengan keuangan pribadi dan laporan keuangan yang tidak tersusun dengan baik. Di tengah kondisi dimana ekonomi mengalami penurunan, pemisahan keuangan dan keberadaan laporan keuangan dapat membantu UMKM sebagai alat ukur pertumbuhan bisnis. Apabila laporan keuangan menunju peningkatan laba dan aset yang cukup signifikan, hal ini menunjukkan bahwa usaha yang dijalankan mengalami perkembangan dan artinya pencapaian usaha sangatlah baik. Sebaliknya, apabila laporan keuangan menunjukan penurunan laba, maka perusahaan harus segera dapat segera melakukan strategi-strategi untuk mencegah kerugian yang lebih besar. Misalnya dengan mengevaluasi dan mengubah sistem pemasaran dengan metode yang lebih efektif, memperbaiki kualitas pengelolaan keuangan dengan kalkulasi yang lebih detail, ataupun inovasi produk.

Dengan menerapkan strategi-strategi tersebut, UMKM khususnya yang bergerak dalam bidang makanan dan minuman yang dikelola oleh keluarga diharapkan dapat bertahan selama masa pandemi Covid-19, dan juga dapat berkembang setelah pandemi Covid-19 usai.

\section{KESIMPULAN}

Cepatnya penyebaran virus Corona (Covid-19) membuat beberapa daerah di Indonesia menetapkan kebijakan Pembatasan Sosial Berskala Besar (PSBB) yang berdampak negatif terhadap operasional dan keberlangsungan bisnis, khususnya bisnis dalam lingkup UMKM. UMKM yang bergerak dalam bidang makanan dan minuman merupakan UMKM yang dianggap paling terdampak akibat adanya Covid- 19 karena penurunan persentase penjualan yang cukup besar. 
UMKM dalam bidang makanan dan minuman yang dikelola oleh keluarga terdampak lebih dari signifikan, baik dalam sisi finansial maupun non finansial. Hal ini disebabkan karena UMKM makanan dan minuman yang yang dikelola oleh keluarga cenderung masih menggunakan teknologi yang relatif sederhana dengan sistem manajemen tidak profesional. Selain itu, UMKM yang dikelola oleh keluarga umumnya kurang memiliki akses terhadap permodalan. Ditambah dengan kemampuan pengelolaan manajemen keuangan yang minim, pelaku usaha UMKM keluarga dalam bidang makanan dan minuman seringkali tidak melakukan pemisahan modal usaha dengan kebutuhan pribadi. Hal-hal tersebut secara tidak langsung menyebabkan kondisi keuangan UMKM yang dikelola keluarga dalam bidang makanan dan minuman tidak stabil, yang kemudian berdampak pada minimnya ruang gerak untuk inovasi strategi maupun produk. Minimnya ruang gerak untuk inovasi strategi maupun produk semakin mendukung keterpurukan UMKM karena PSBB akibat adanya pandemi Covid-19.

Kekuatan mental, adaptasi serta kemauan untuk terus belajar dan berkembang para pelaku UMKM keluarga bidang makanan dan minuman sangat diuji selama masa pandemi Covid-19. Peran pemilik bisnis dan kekompakan keluarga sangat dibutuhkan.

Pelaku usaha perlu memahami jika hanya mengandalkan bantuan dari pemerintah, UMKM tetap akan sulit untuk bertahan selama masa pandemi Covid-19. Oleh karena itu, sembari memanfaatkan bantuan finansial yang diberikan oleh pemerintah, UMKM makanan dan minuman milik keluarga harus tetap bersikap pro-aktif dalam menerapkan strategistrategi pengelolaan usaha yang dapat membantu bisnis menghadapi masa kritis pada masa PSBB karena pandemi Covid-19. Strategi yang diterapkan harus bersifat adaptif dimana strategi yang diterapkan harus sesuai pada kondisi keuangan UMKM maupun kebijakan pemerintah yang terus berubah akibat pandemi Covid-19.

Dengan demikian, UMKM khususnya yang bergerak dalam bidang makanan dan minuman yang dikelola oleh keluarga diharapkan dapat bertahan selama masa pandemi Covid-19, dan dapat berkembang setelah pandemi Covid-19 usai.

Adapun di bawah ini adalah beberapa saran dari peneliti terkait dengan kepentingan penelitian selajutnya, yaitu:

1. Memperdalam penelitian mengenai UMKM yang dikelola oleh keluarga (merupakan bisnis keluarga) di wilayah Indonesia.

2. Memperluas penelitian mengenai UMKM dalam bidang makanan dan minuman di Indonesia. 
3. Mengadakan penelitian mengenai UMKM yang mengkhususkan pada UMKM bidang makanan dan minuman yang dikelola oleh keluarga.

\section{UCAPAN TERIMA KASIH}

Penelitian ini dapat dilaksanakan dengan baik berkat bantuan dari berbagai pihak. Secara khusus, peneliti mengucapkan terima kasih kepada Bapak Liem Gai Sin dan Bapak Sarbini Wono selaku dosen pembimbing pada saat penelitian ini dilakukan.

\section{DAFTAR PUSTAKA}

Amelia, L., Purbolaksono, A., \& Syahayani, Z. (2017, February). Analisis Peta Industri Makanan dan Minuman di Indonesia. Retrieved from The Indonesian Institute: https://adoc.pub/queue/analisis-peta-industri-makanan-dan-minuman-diindonesia.html

Aminah, A. N. (2020, March 17). Ini Usulan Hipmi untuk Gairahkan UMKM Makanan dan Minuman. Retrieved from REPUBLIKA:

https://republika.co.id/berita/q7cgdn384/ini-usulan-hipmi-untuk-gairahkan-umkmmakanan-dan-minuman

Burhan, F. A. (2020, April 15). Bisnis Anjlok akibat Pandemi Corona, UMKM Bisa Ubah Strategi Usaha. Retrieved from Kata Data: https://katadata.co.id/agustiyanti/digital/5e9a41c9131de/bisnis-anjlok-akibatpandemi-corona-umkm-bisa-ubah-strategi-usaha

Capri, A. (2018, October). MICRO AND SMALL BUSINESSES IN INDONESIA 'S DIGITAL ECONOMY: KEYS TO DEVELOPING NEW SKILLS AND HUMAN CAPITAL. Retrieved from Asian Pasific Foundation of Canada: https://apfcanadamsme.ca/sites/default/files/2019-

03/Micro\%20and\%20Small\%20Businesses\%20in\%20Indonesia’s\%20Digital\%20E conomy.pdf

CNN. (2020, April 28). Transaksi Online Produk UMKM Naik 350 Persen Saat Corona. Retrieved from CNN Indonesia: https://www.cnnindonesia.com/ekonomi/20200428194546-92-498232/transaksionline-produk-umkm-naik-350-persen-saat-corona

Deloitte. (2020). Deloitte Indonesia Business and Industry Updates. Retrieved from Deloitte: https://www2.deloitte.com/content/dam/Deloitte/id/Documents/consumerbusiness/id-consumer-covid19-2020.pdf

Hamzani, U., \& Achmad, D. (2017). Micro, Small and Medium Enterprises (MSMEs) Coaching Program. Journal of Business and Economics Review, 2(3), 20-25.

Harmawan, B. N. (2020, April 13). Stimulus UMKM di Tengah Badai Corona. Retrieved from Detik News: https://news.detik.com/kolom/d-4974884/stimulus-umkm-ditengah-badai-corona

Haryanti, D. M., \& Hidayah, I. (2018, July 24). Potret UMKM Indonesia: Si Kecil yang Berperan Besar. Retrieved from www.ukmindonesia.id: https://www.ukmindonesia.id/baca-artikel/62

Hasan, I. (2002). Pokok-Pokok Materi Metodologi Penelitian dan Aplikasinya. Jakarta: Ghalia Indonesia. 
Herlinda, W. D. (2020, April 18). Sepekan Lebih PSBB di Jakarta, Bagaimana Saran dan Kritik dari Dunia Usaha? Artikel ini telah tayang di Bisnis.com dengan judul "Sepekan Lebih PSBB di Jakarta, Bagaimana Saran dan Kritik dari Dunia Usaha?", Klik selengkapnya di sini: https://ekonomi.bisn. Retrieved from Ekonomi Bisnis: https://ekonomi.bisnis.com/read/20200418/12/1229069/sepekan-lebih-psbbdi-jakarta-bagaimana-saran-dan-kritik-dari-dunia-usaha

Hidranto, F. (2020, April 19). Ekstra Insentif Agar UMKM Tetap Aktif. Retrieved from indonesia.go.id: https://indonesia.go.id/kategori/indonesia-dalamangka/1780/ekstra-insentif-agar-umkm-tetap-aktif

Iskandar. (2020, April 20). Dampak Covid-19, Belanja Makanan dan Minuman Online Naik 143 Persen di Indonesia. Retrieved from Liputan6:

https://www.liputan6.com/tekno/read/4232324/dampak-covid-19-belanja-makanandan-minuman-online-naik-143-persen-di-indonesia

Lidyana, V. (2020, April 8). Dampak PSBB ke Ekonomi dan Pesan untuk Anies. Retrieved from Detik Finance: https://finance.detik.com/berita-ekonomi-bisnis/d4969028/dampak-psbb-ke-ekonomi-dan-pesan-untuk-anies

LPPI, \& BI. (2015, September). PROFIL BISNIS USAHA MIKRO, KECIL DAN MENENGAH (UMKM). Retrieved from www.bi.go.id: https://www.bi.go.id/id/umkm/penelitian/Documents/Profil\%20Bisnis\%20UMKM. pdf

Mahardika, R. B. (n.d.). Mengenal Industri Makanan dan Minuman di Era Industria 4.0. Retrieved from Forbil Institute:

https://forbil.org/manage/statics/publication/21/Forbil_EBook_Series_OktI_Industri_Makanan_dan_Minuman.pdf

Mahlizal, F., Priatna, W. B., \& Burhanuddin. (2016). Pengaruh Keluarga Dan Lingkungan Ekonomi Terhadap Kinerja Usaha Tahu Di Kabupaten Bogor. Jurnal Agribisnis Indonesia, 4(1), 17-26.

Nurhidayat, D. (2020, April 16). Pemerintah Siap Bantu 37 Ribu UMKM Terdampak Covid-19. Retrieved from Media Indonesia: https://mediaindonesia.com/ekonomi/304617/pemerintah-siap-bantu-37-ribuumkm-terdampak-covid-19

Paramaesti, C. (2018, September 16). Industri Makanan dan Minuman Tumbuh 8, 67 Persen Triwulan II 2018. Retrieved from Bisnis Tempo: https://bisnis.tempo.co/read/1127039/industri-makanan-dan-minuman-tumbuh-867persen-triwulan-ii-2018/full\&view $=$ ok

Pernando, A. (2020, March 27). Riset : Industri F\&B Paling Terdampak Pandemi Corona. Retrieved from Ekonomi Bisnis:

https://ekonomi.bisnis.com/read/20200327/12/1218688/riset-industri-fb-palingterdampak-pandemi-corona

Putra, D. A. (2020, April 12). Dampak Virus Corona, Industri Makanan Kesulitan Bahan Baku \& Harga Mahal. Retrieved from Merdeka:

https://www.merdeka.com/uang/dampak-virus-corona-industri-makanan-kesulitanbahan-baku-harga-mahal.html

PwC. (2014, September). Survey Bisnis Keluarga 2014 Indonesia. Retrieved from www.pwc.com/id: https://www.pwc.com/id/en/publications/assets/indonesiareport-family-business-survey-2014.pdf

Rahadi, D. R. (2017). ranformasi Inovasi Bisnis Keluarga Dalam Mendukung Ekonomi Kreatif. Jurnal Ecoment Global, 2(1), 1-11. 
Samsiah, S., \& Lawita, N. F. (2017). Review the Readiness of MSMEs in Indonesia Compliance with Accounting Standards Micro, Small and Medium Enterprise (SAK EMKM). Jurnal Akuntansi \& Ekonomika, 7(2), 115 - 120.

Setyowati, D. (2020, April 21). UMKM Bertahan, Pandemi Corona Ciptakan Tren Baru di Bisnis Kuliner Artikel ini telah tayang di Katadata.co.id dengan judul "UMKM Bertahan, Pandemi Corona Ciptakan Tren Baru di Bisnis Kuliner", https://katadata.co.id/desysetyowati/digital/5e9e858dbacb4/u. Retrieved from Kata Data: https://katadata.co.id/desysetyowati/digital/5e9e858dbacb4/umkm-bertahanpandemi-corona-ciptakan-tren-baru-di-bisnis-kuliner

Staff, M. C. (2021, July 14). Coronavirus disease 2019 (COVID-19). Retrieved from Mayo Clinic: https://www.mayoclinic.org/diseases-conditions/coronavirus/symptomscauses/syc-20479963? $\mathrm{p}=1$

Syaodih, N. (2009). Metode Penelitian Pendidikan. Bandung: PT. Remaja Rosdakarya.

Waseso, R. (2020, April 21). Bisnis UMKM olahan makanan paling terdampak corona. Retrieved from Nasional Kontan: https://nasional.kontan.co.id/news/bisnis-umkmolahan-makanan-paling-terdampak-corona

Widyamurti, E. (2020, April 18). Gov't Braces for Economic Slowdown Due to LargeScale Social Restrictions. Retrieved from Cabinet Secretariat of The Republic of Indonesia: https://setkab.go.id/en/govt-braces-for-economic-slowdown-due-tolarge-scale-social-restrictions/

Wijaya, C. (2020, April 16). Virus corona: Sejumlah usaha kecil dan menengah 'tutup hingga rumahkan karyawan', pemerintah diminta 'dahulukan bantuan bagi usaha strategis'. Retrieved from BBC News Indonesia: https://www.bbc.com/indonesia/indonesia-52283321

Yasa, G. N. (2016). Indonesia SMEs: Increased Government Support to Overcome Challenges . Retrieved from Global Business Guide Indonesia: http://www.gbgindonesia.com/en/main/why_indonesia/2016/indonesia_smes_incre ased_government_support_to_overcome_challenges_11603.php

(C) 2021 by authors. Content on this article is licensed under a Creative Commons Attribution 4.0 International license. (http://creativecommons.org/licenses/by/4.0/). 